\title{
DEPENDENT DAN INDEPENDENT SPEAKER UNTUK KONTROL PERALATAN RUMAH TANGGA MELALUI PENGENALAN WICARA
}

\author{
Sri Utami \\ Jurusan Teknik Konversi Energi Politeknik Negeri Bandung \\ Email : utamiwu@yahoo.com
}

\begin{abstract}
Abstrak
Konsumsi energi dapat dikurangi salah satunya dengan pengontrolan dan monitoring peralatan rumah tangga setiap waktu. Pengontrolan akan lebih efektif bila bisa dilakukan setiap saat dan melalui pengenalan wicara. Pengenalan wicara diimplementasikan untuk mengontrol dan memonitoring peralatan rumah tangga jarak jauh. Proses kontrol dilakukan dari PC client ke PC server. Sistem ini mempunyai input berupa dependent dan independent speaker. Independent speaker digunakan untuk mengetahui sistem bisa bekerja untuk speaker yang bukan merupakan speaker standar. Proses yang digunakandalampenelitianiniadalahpengambilansinyal, sampling, frame, windowing, LPC (Linear Prediction Code). Proses-proses tersebutdinamakansebagai proses ekstraksi. Setelahitudilakukan proses Dynamic Time Warping (DTW) untuk memadankan sinyal masukan dengan sinyal standar. Proses ekstraksidan Dynamic Time Warping dilakukanpada PC client, hasilnya dikirim ke server untuk mengontrol alat yang diinginkan. Setelah alat terkontrol, perangkat keras akan memberikan feedback ke PC server kemudian mengirimkanny ake PC client. Di PC client dapat diketahui kondisi peralatan yang dikontrol. Alat yang dikontrol adalah empat buah lampu. Sistem yang dibangun mempunyai prosentase keberhasilan rata-rata 100\% dependent speaker (pengucap yang suaranya dipakai sebagai standar) dan prosentase keberhasilan rata-rata $71,88 \%$ untuk independent speaker (pengucap yang suaranya tidak dipakai sebagai standar).
\end{abstract}

Kata Kunci: dependent dan independent speaker, DTW

\begin{abstract}
Energy consumption can be reduced by controlling and monitoring household appliances at all times. Speech recognition was implemented to control and monitor home appliances remotely. The system based on dependent and independent speaker models. Independent speaker was used to determine the system works for speakers that are not standard. The process were taking signals, sampling , frames, windowing, LPC (Linear Prediction Code) and called the extraction process. Then Dynamic Time Warping (DTW) match the input signal with a standard signal. Extraction and Dynamic Time Warping process were on the client PC, the result was sent to the server to control the desired device. The hardware will provide feedback to the server PC and then sends it to the client PC.The condition of the equipment being controlled can be seen on the client PC. The controlled device are four lamps. The system has an average success percentage $100 \%$ for dependent speaker and $71.88 \%$ for independent speaker.
\end{abstract}

Key Words: dependent dan independent speaker, DTW 


\section{PENDAHULUAN}

Penghematan energi dapat dicapai dengan mengurangi konsumsi dan kegiatan yang menggunakan energi. Manfaat yang diperoleh sama tapi dengan tingkat efisiensi yang jauh lebih tinggi, bisa dilakukan salah satunya dengan mengontrol peralatan rumah tangga. Peralatan rumah tangga yang merupakan kebutuhan sehari-hari bila digunakan secara bijaksana akan menyebabkan berkurangnya biaya.

Penggunaan energi dikendalikan berdasarkan perintah yang dilakukan secara manual, wireless, timer, pengendalian jarak jauh, dan pengendalian jarak jauh dengan pengenalan wicara. Intelligent personal assistant dan knowledge navigator yang merupakan salah satu aplikasi yang ada pada iPhone $4 \mathrm{~S}$ telah memanfaatkan efek suara untuk pengendalian. Dewantara $^{[2]}$ membuat aplikasi pengenalan wicara untuk perintah nirkabel robot mikro mouse, Anggraeni dan Astutik $^{[1]}$ menggunakan pengenalan wicara untuk mengakses suatu jaringan sebagai password.

Di samping itu, dalam beberapa tahun terakhir ini perkembangan dunia telekomunikasi mengalami kemajuan yang sangat pesat, sehingga pengendalian berbasis suara telah dimanfaatkan dalam berbagai kebutuhan, khususnya dalam pengoperasian energi pada smart building.

Indikasi sumber suara dibedakan berdasarkan pemilik system (dependent) dan lainnya (independent). Signifikasi suara berbasis dependent dan independent perlu diterjemahkan secara akurat sehingga dapat dikenali oleh perangkat kendalinya.

\section{METODOLOGI}

Speaker yang selama ini diterapkan dalam sebuah sistem kendali adalah dependent speaker. Dalam beberapa keadaan, dibutuhkan independent speaker untuk mengendalikan peralatan dalam sistem kendali. Salah satunya adalah peralatan rumah tangga mengingat semakin majunya aspek teknologi yang diterapkan. Sistem dengan dependent speaker diperlukan salah satunya untuk sistem yang digunakan untuk kepetingan umum/bersama. Dengan adanya perbandingan dependent dan independent speaker maka dapat diketahui kehandalan sistem yang bisa mengendalikan dan memonitoring peralatan tertentu.

Sistem keseluruhan seperti yang tersaji pada Gambar 1. Speaker pada blok diagram Gambar 1 memberikan suaranya sebagai masukan lewat mikrofon. Masukan ini akan diolah dalam $P C$ client mulai dari proses sampling, frame, windowing, FFT, LPC. Kemudian hasil dari LPC dicari pemadanan dengan LPC dari sinyal standar yang telah tersimpan sebagai database di dalam PC client. Hasil dari DTW tersebut akan dikirimkan ke $P C$ server melalui TCP/IP untuk diproses menjadi suatu perintah ke perangkat keras yang dikendalikan. Perintah tersebut merupakan bentuk implementasi dari perintah yang diberikan dari $P C$ client.

Sebaliknya dengan adanya perubahan kondisi pada peralatan yang diinginkan, maka terjadisinyal balikan yang berupa sinyal DTMF yang dikirimkan oleh perangkat keras ke $P C$ server. Oleh $P C$ server sinyal ini diolah untuk dikenali sebagai suatu kondisi tertentu yang akan dikirimkan ke $P C$ client sebagai laporan tentang kondisi alat yang diinginkan. 


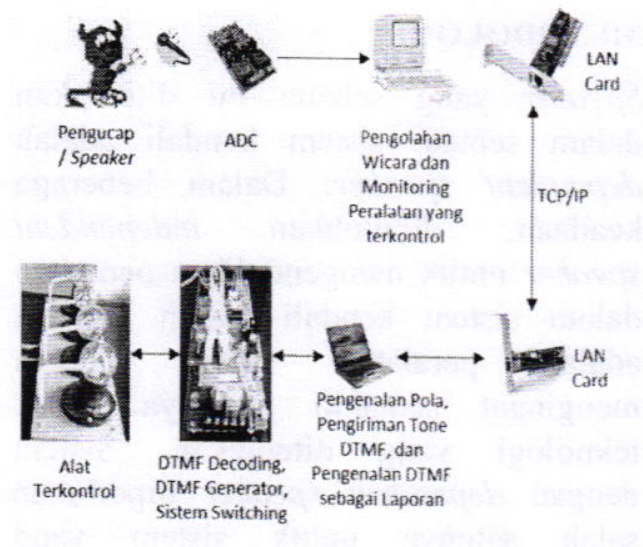

Gambar 1. Blok Diagram Sistem Pengendalian Lampu berbasis Wicara

\section{Sinyal Suara Manusia}

Manusia menggunakan suara sebagai sumber informasi untuk mengkomunikasikan keinginan, ide dan perasaannya kepada orang lain. Sinyal wicara adalah sinyal yang dihasilkan oleh suara manusia yang mempunyai frekuensi kerja antara 0 sampai dengan $5000 \mathrm{~Hz}$. Pada program Snack yang akan digunakan, frekuensi sampling diset pada $12 \mathrm{kHz}$. Frekuensi sampling ini dipilih karena biasa digunakan untuk voice, sedangkan untuk telephone biasa digunakan frekuensi sampling sebesar 8 $\mathrm{kHz}$.

Gambar 2 merupakan proses ekstraksi suara yang akan digunakan dalam proses pengenalan wicara yang digunakan dalam sistem kendali. Proses ini dimulai dari masukan berupa sample suara yang akan digunakan dalam sistem.

Data yang digunakan sebagai data standar merupakan data 8 kombinasi kata, yaitu: satu nyala, satu mati, dua nyala, dua mati, tiga nyala, tiga mati, empat nyala, empat mati.

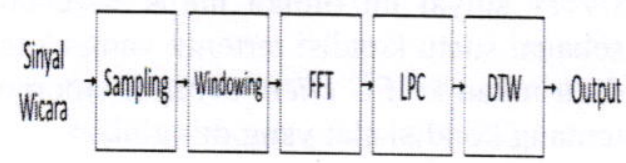

Gambar 2. Proses Ekstraksi Sinyal Wicara

\section{Sampling}

Sinyal wicara merupakan sinyal yang tidak terbatas dalam domain waktu (finite time interval). Untuk keperluan pemrosesan dalam transformasi Fourier, maka sinyal wicara harus dibentuk dalam potongan-potongan waktu yang terbatas (infinite time interval). Karena itu sinyal yang ada dipotong-potong dalam slot-slot interval waktu tertentu.

\section{Windowing}

Windowing merupakan proses pengurangan efek diskontinyuitas pada awal dan akhir masing-masing sinyal yang telah di-frame ${ }^{[4]}$. Jenis window yang digunakan adalah window Hamming.

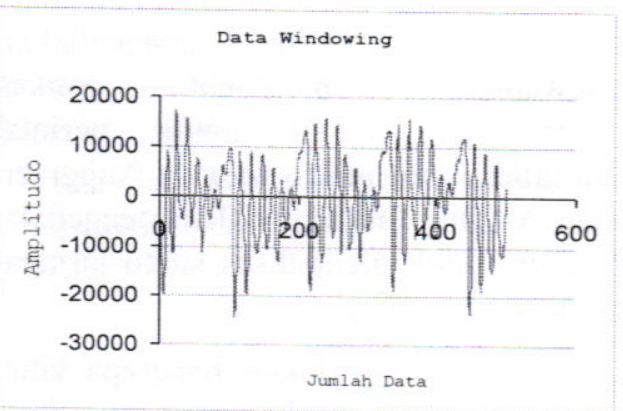

Gambar 3. Hasil Windowing Data Sampel Kata "empatmati" milidetik ke-13900

Gambar 3 menunjukkan proses windowing yang telah dilakukan. Dari gambar tersebut bisa diamati bahwa window Hamming menyebabkan sinyal yang disampel menjadi lebih halus bila dibandingkan dengan sinyal yang belum melalui proses windowing. Hal ini menunujukkan bahwa windowing berfungsi untuk mengurangi efek diskontinyuitas pada ujung-ujung frame. 


\section{Fourier Transform}

Fast Fourier Transform (FFT) adalah suatu metode yang sangat efisien untuk menyelesaikan Transformasi Fourier diskrit (DFT) yang banyak dipakai untuk keperluan analisa sinyal. Sehingga dengan DFT sinyal yang di-sampling dalam domain waktu ditransformasikan ke domain frekuensi.

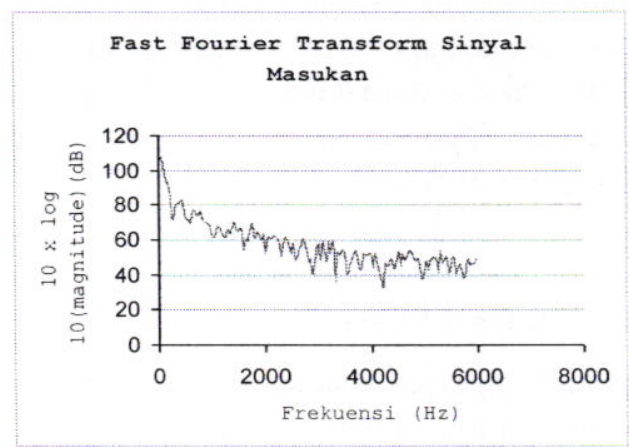

Gambar 4. Fast Fourier Transform Sinyal Masukan dengan Menggunakan Perangkat Lunak Tcl/Tk dan Snack

Setiap sinyal yang berasal dari alam merupakan sinyal analog yang bila diolah harus diubah ke dalam bentuk sinyal digital. Pengolahan dalam bentuk digital merupakan pengolahan dalam bentuk diskrit. Dalam penelitian ini, sinyal dalam domain waktu diubah ke dalam domain frekuensi dengan 256 titik. Karena hasil yang diperoleh berupa hasil fungsi konvolusi, maka hanya diambil 128 titik yang akan diolah dalam proses berikutnya. Sedangkan 128 sisanya tidak dipergunakan karena berupa pencerminan.

Gambar 4 merupakan sinyal suara yang sebelumnya berada dalam domain waktu telah diubah dalam domain frekuensi. Hasil Fast Fourier Transform, sinyal masukan menunjukkan sebaran spektrum frekuensi dari sinyal suara yang telah dihasilkan oleh pengucap antara 0 sampai dengan $6000 \mathrm{~Hz}$.

\section{Linear Prediction Code}

Linear Prediction Code (LPC) merupakan proses pencarian ciri dari sinyal wicara yang akan diolah. Linear Prediction Code (LPC) secara umum sebagai pemroses front-end untuk pengenalan wicara, perlu diketahui alasan mengapa LPC banyak digunakan $^{[5]}$, yaitu:

- LPC menyuguhkan model yang bagus untuk sinyal wicara. Cara yang digunakan LPC untuk analisa sinyal wicara sangat beralasan untuk pemisahan track dari sumber vokal.

- LPC adalah sebuah model traktabel secara analitis.

- Model LPC bekerja dengan baik pada aplikasi pengenalan.

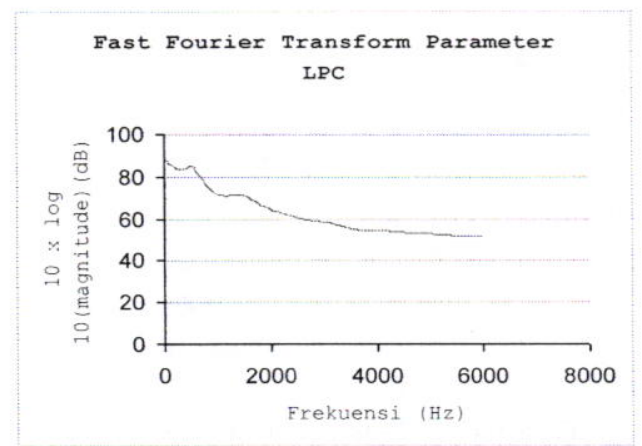

Gambar 5. Fast Fourier Transform LPC dengan Menggunakan Perangkat Lunak TCL/Tk dan Snack

Parameter LPC yang di-fourier transform-kan seperti ditunjukkan pada Gambar 5 akan menjadi selubung spektrum dari spektrum sinyal masukan. Untuk menggambarkan ciri atau fitur wicara dalam domain waktu, maka LPC spectrum di-invers fast fourier-kan.

\section{Dynamic Time Warping}

Dynamic Time Warping (DTW) merupakan cara untuk memadankan sinyal standar dengan sinyal input. Dengan menggunakan DTW, dua buah sinyal suara dibandingkan vektor-vektor 
spektralnya seperti ditunjukkan pada Gambar 6, dimana terdapat proses pembandingan panjang sinyal antara dua buah sinyal tersebut, sehingga terjadi proses pemadanan panjang sinyal dengan cara memperpanjang dan menekuk vektor spektralnya. Memperpanjang dalam arti memperpanjang sinyal yang lebih pendek dengan memperhatikan perbandingan vektor spektralnya. Demikian pula dengan menekuk, yaitu menekuk sinyal yang lebih panjang dengan memperhatikan vektor spektralnya. Dengan panjang yang sama sebagai hasil DTW maka jarak euclidian antara sinyal dapat diperbandingkan atau dihitung.

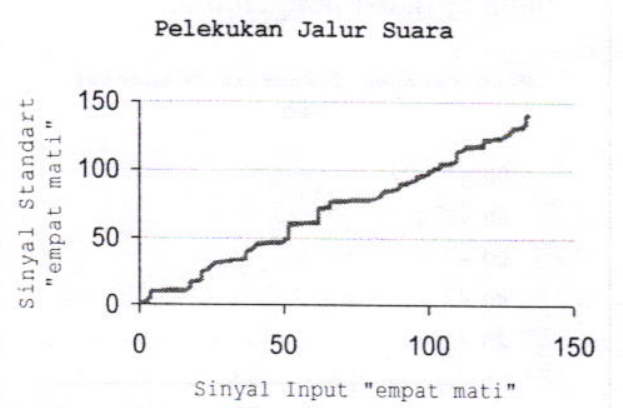

\section{Gambar 6. Pelekukan Jalur Suara dengan Dynamic Time Warping}

\section{Socket Programming}

Socket programing adalah suatu aplikasi program yang dapat membantu sistem komunikasi antar satu sistem komputer dengan sistem komputer lain dengan menggunakan protokol TCP/IP dan protokol lain yang terhubung.

Speaker memberikan suaranya sebagai masukan lewat mikrofon. Masukan ini akan diolah dalam $P C$ client mulai dari proses sampling, frame, windowing, FFT, LPC. Kemudian hasil dari LPC dicari pemadanan (DTW) dengan LPC dari sinyal standar yang telah tersimpan sebagai basis data di dalam PC client. Hasil dari DTW tersebut akan dikirimkan ke $P C$ server melalui TCP/IP untuk diproses menjadi suatu perintah ke perangkat keras. Perintah tersebut merupakan bentuk implementasi dari perintah yang diberikan dari $P C$ client.

Sebaliknya, dengan adanya perubahan kondisi pada peralatan yang diinginkan, maka terjadi sinyal balikan yang berupa sinyal DTMF yang dikirimkan oleh perangkat keras ke $P C$ server. Oleh $P C$ server sinyal DTMF ini diolah untuk dikenali sebagai suatu kondisi tertentu yang akan dikirimkan ke $P C$ client sebagai laporan tentang kondisi alat yang diinginkan

\section{HASIL DAN PEMBAHASAN}

Pada pengujian sistem, diambil sampel data dari dua orang yang terdiri dari dua orang pria. Pria pertama merupakan standar sekaligus pengisi suara untuk perintah yang digunakan. Pria kedua merupakan pembanding untuk mengetahui unjuk kerja sistem bila perintah dilakukan oleh suara yang bukan merupakan pengisi suara standar (independent speaker).

Identifikasi wicara sebagai perintah pengendalian lampu (Gambar 1) disimulasikan melalui suara pria 1 (dependent speaker) dan pria 2 sebagai independent speaker. Hasil pengujian dapat dilihat pada Tabel 1. Speaker memberikan perintah "satu nyala, satu mati, dua nyala, dua mati, tiga nyala, tiga mati, empat nyala, empat mati" kepada sistem yang diuji.

Pada Tabel 1 terlihat bahwa pengujian pada pria 1 yang digunakan sebagai standar (dependent speaker) memperoleh persentase keberhasilan rata-rata untuk semua perintah adalah sebesar $100 \%$. Pengujian yang kedua adalah pengujian yang dilakukan oleh pria 2 atau independent speaker (pria lain yang suaranya tidak dipakai sebagai standar). Persentase keberhasilan ratarata yang didapat untuk semua perintah 
$71,88 \%$. Hal ini menunjukkan bahwa untuk suara yang dijadikan sebagai standar, sistem berhasil mengenali dan memberi respon sebagaimana perintah yang diberikan. Untuk suara yang tidak dijadikan sebagai standar keberhasilan sistem tidak setinggi jika dibandingkan dengan suara yang dijadikan standar. Hal ini menunjukkan sinyal masukan dan sinyal standar yang berbeda. Dari hasil pengujian menunjukkan ciri sinyal suara yang dihasilkan oleh speaker pertama sama dengan pemberi standar, sedangkan untuk speaker ke dua, speaker dan pemberi standar mempunyai ciri sinyal suara yang mendekati sama.

Tabel 1. Tingkat Keberhasilan Sistem Perangkat Lunak

\begin{tabular}{|c|c|c|c|c|}
\hline No. & PENGUCAP & PERINTAH & $\begin{array}{c}\text { BANYAK } \\
\text { PERCOBAAN } \\
\end{array}$ & $\begin{array}{c}\text { PERSENTASE } \\
\text { KEBERHASILAN }\end{array}$ \\
\hline 1 & \multirow{8}{*}{ Pria 1} & 1 nyala & 8 kali & $100 \%$ \\
\hline 2 & & 1 mati & $8 \mathrm{kali}$ & $100 \%$ \\
\hline 3 & & 2 nyala & 8 kali & $100 \%$ \\
\hline 4 & & 2 mati & 8 kali & $100 \%$ \\
\hline 5 & & 3 nyala & $8 \mathrm{kali}$ & $100 \%$ \\
\hline 6 & & 3 mati & 8 kali & $100 \%$ \\
\hline 7 & & 4 nyala & 8 kali & $100 \%$ \\
\hline 8 & & 4 mati & $8 \mathrm{kali}$ & $100 \%$ \\
\hline \multicolumn{4}{|c|}{ RATA-RATA } & $100 \%$ \\
\hline 9 & \multirow{8}{*}{ Pria 2} & 1 nyala & 4 kali & $100 \%$ \\
\hline 10 & & 1 mati & 4 kali & $75 \%$ \\
\hline 11 & & 2 nyala & 4 kali & $75 \%$ \\
\hline 12 & & 2 mati & 4 kali & $50 \%$ \\
\hline 13 & & 3 nyala & 4 kali & $50 \%$ \\
\hline 14 & & $3 \mathrm{mati}$ & 4 kali & $75 \%$ \\
\hline 15 & & 4 nyala & 4 kali & $50 \%$ \\
\hline 16 & & 4 mati & 4 kali & $100 \%$ \\
\hline \multicolumn{4}{|c|}{ RATA-RATA } & $71,88 \%$ \\
\hline
\end{tabular}

\section{KESIMPULAN}

Sistem yang diuji mempunyai tingkat akurasi yang tinggi untuk pengucap masukan dan pengucap standar yang sama (dependent speaker). Hal ini dibuktikan dengan hasil pengujian yang dilakukan oleh pria pertama. Sedangkan untuk pengujian yang dilakukan oleh suara lain (independent speaker) tingkat keberhasilannya bervariasi dari $50 \%$ sampai dengan $100 \%$. Hal ini disebabkan karena suara pria kedua tidak pernah berinteraksi dengan sistem. Keberhasilan sistem ditunjukkan dengan ketepatan penyalaan/pematian lampu sesuai dengan yang diperintahkan melalui perintah suara.

\section{DAFTAR PUSTAKA}

1. Anggraeni, Triana Dewi, Astutik, Debi Puji, Pengenalan Wicara dengan Penutur Tak Bebas, PENS ITS 2003

2. Dewantara, Bima Sena Bayu, Aplikasi Pengenalan Wicara untuk Perintah Nirkabel Robot Mikro Mouse

3. Dutono, Titon, Penataran Kebahasaan Tahap I :Fonetik Dan Fonologi -Pengolahan Sinyal Wicara Digital, 2001

4. Gabel, Robert A, Richard A Robert, SinyaldanSistemLinier,Erlangga 1996

5. Rabiner, Lawrence, Huang Juang, Biing, Fundamentals of Speech Recognition, Prentice Hall International Inc, 1993

6. Proakis, John G, Malonakis, Dimitris G, Digital Signal Processing Principles, Algorithms, and Applications, Prentice Hall, Inc., New Jersey, 1995 